\title{
局部座屈により耐力劣化した角形鋼管柱の被災後補修法 鋼部材の被災後補修に関する研究 その 1 \\ SEISMIC REPAIR TO THE DAMAGED RHS COLUMN WITH STRENGTH DETERIORATION DUE TO THE LOCAL BUCKLING
}

Development of seismic repair for the damaged steel members Part 1

吉敷祥一*, 岩㟝祐介**

\section{Shoichi KISHIKI and Yusuke IWASAKI}

\begin{abstract}
From lessons learned after the 2011 Tohoku earthquake, it is clear that the quick procurement of an emergency public shelter and restoration of the city function are very important in the event of a disaster. This paper focuses on effects of the seismic repair to the residual out-of-plane deformations in local buckling region of steel column. The major findings obtained from the test are summarized as follows: (1) the RA repair method brought the strength recovery from the residual strength and the maximum strength is larger than the original one; (2) RF and RW repair method also brought the strength recovery from the residual strength, however, the maximum strength is roughly same as the plastic moment of the original column; (3) finally, a simple seismic repair procedure using the additional plate to the damaged column is proposed.
\end{abstract}

Keywords : RHS column, local buckling, strength deterioration, seismic repair, cyclic loading test 角形鋼管柱, 局部座屈, 耐力劣化, 被災後補修, 繰り返し載荷実験

\section{1. はじめに}

柱や梁の塑性変形能力に立脚した耐震設計は, 極大地震時におけ る各部材の塑性化やそれに伴う残留変形を許容しており, 必ずしも 建築物の機能維持を保証したものではない. 近年の度重なる大地震 の発生と被害を受け,一般の人々の間でも建築物の倒壊防止による 人命保護は当然とし, 地震後も継続して使い続けられる建築物の実 現が広く求められるようになっている.免震や制振などの損傷制御 技術は, 人々の要望に応えうる手段の一つではあるが, 先に述べた 柱や梁の塑性変形能力に立脚した耐震構造 (設計) がある限り, 地震 後に喪失した耐震性能の回復を図る被災後補修技術が必要である.

鋼部材の被災後補修に関する体系的な研究としては, 1981年〜 85 年に建設省の総合技術開発プロジェクト「震災構造物の復旧技術 の開発」1などが実施され, そのなかで局部座屈が生じた $\mathrm{H}$ 形断面部 材の被災後補修が検討された 2) 4) など. また, この間に日本建築学会 大会学術講演 (1982年) の研究協議会「震災構造物の損傷評価と修 復」が行われ, 1978年宮城県沖地震における被害とその後の復旧状 況 $^{5)}$ を踏まえた議論が行われている ${ }^{6}$.これら活発な研究活動の成 果は, 「震災建築物の被災度区分判定基準および復旧技術指針」7)の 前身である「震災建築物等の被災度判定基準および復旧技術指針」 (1991年)にまとめられ, 現行指針はその大部分を引き継いでいる. 一方, 1994年のノースリッジ地震と翌年の兵庫県南部地震では,

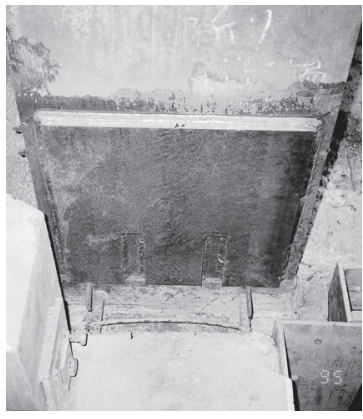

(a) Cover plate type

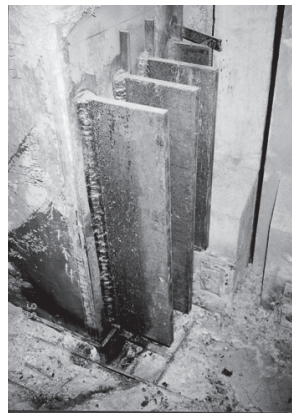

(b) Rib plate type
Photo 1 Seismic repair for RHS column after the Kobe Earthquake ${ }^{7)}$

梁端溶接部の破断被害が数多く見られ,この部位の被災後補修に関 する研究が精力的に行われた ${ }^{8)}$ 10)など.また, それまでの補修技術 が網羅していない複雑かつ大規模な被害が見られたこと, 被災建築 物の再使用のために早急な復旧工事が求められたことから, 鋼部材 に対する復旧技術を検討・考案し, 実際の復旧工事が進められた報 告もある ${ }^{11}$. 例えばPhoto1は角形鋼管柱に対する被災後補修を行っ た事例である7). しかし, 兵庫県南部地震以降の被災後補修に関寸 る研究12) 15)などは少なく, 実際に行われた補修法であっても, どの ような損傷状況に適用でき, どのように補修部位を構成するべき か, また,それらがじのような効果をもたらすかは明らかでない，
* 東京工業大学科学技術創成研究院未来产業技術研究所 准教授. 博士 (工学)

** 元 大阪工業大学大学院 大学院生 . 修士 (工学) (現 能勢建築構造研究所)
Assoc. Prof., FIRST, IIR, Tokyo Institute of Technology, Dr.Eng.

Former Grad. Student, Osaka Institute of Technology, M.Eng. (Nose Structural Engineering) 
本研究では, 損傷した鋼部材に対して補修を施す一連の構造実験 を実施し, その効果を分析することにより, 鋼部材の被災後補修法 を構築する.本論文では研究の第一段階として, 局部座屈により耐 力劣化した角形鋼管柱へのカバープレート補修法 (photo1 (a)) 7) を対 象とした実験を行い, 損傷度を考慮した被災後補修法を構築する. なお, 例えば文献11) では, 損傷前と同程度まで耐力を回復させる ことを“補修 (Seismic Repair)”, 損傷前の元断面以上に耐力を回復 させることを “補強 (Strengthening)” と定義している. しかし, 既 存部材に対する一般的な補強 (Seismic Retrofit) とは異なり,いずれ も損傷した部材の耐力低下を考慮する必要があると考えられること から, 本研究では被災後の補修・補強を区別せず, 両者を“被災後 補修”, あるいは単に“補修”と呼ぶこととする。

\section{2. 実験計画}

\section{1 実験の概要}

本章では, 局部座屈により耐力劣化した角形鋼管柱のカバープ レート補修法の効果を確認するために実施した, 角形鋼管柱の一定 軸力下での繰り返し載荷実験の計画について説明する.実験の流れ をFig.1に示す. 実験は, 局部座屈による耐力劣化などの損傷を生 じさせる “損傷実験”と, 被災後補修を施してその効果を確認する

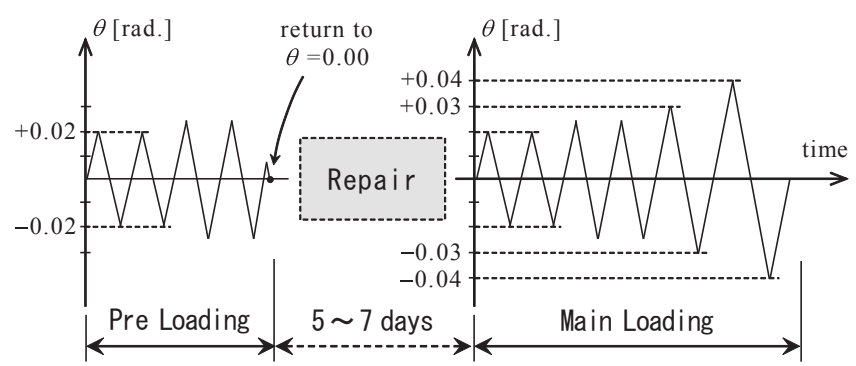

Fig. 1 Test sequence (example)

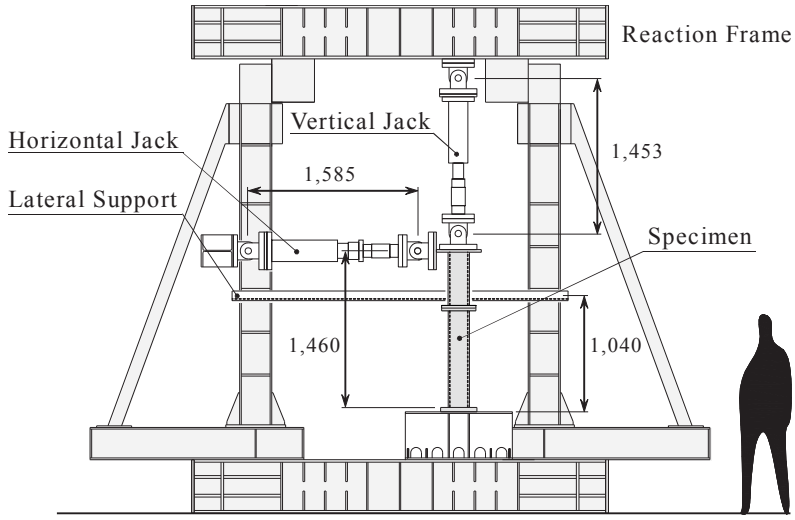

Fig. 2 Test setup
“補修実験”の2段階で行った。つまり，1体の試験体に対して2度 の載荷実験を行ったことになる.

\section{2 載荷方法と載荷履歴}

試験体を含むセットアップの概要をFig.2 に示す. 載荷装置は, 自 己釣合型反カフレームに試験体の柱脚部を固定し,柱頭部に水平と 鉛直の 2 台の油圧ジャッキを接続して構成する.載荷は, 鉛直ジャッ キにより所定の軸力を与えた後, 水平ジャッキにより繰り返し変形 を与えることで行った.軸力は, ジャッキの傾きなどを考慮して一 定值を保つように荷重制御した。また, 実験中は試験体の脚部に作 用する曲げモーメント $M$, 軸力 $N$, および部材角 $\theta$ を計測するとと もに, 局部座屈の発生位置と板面外の変形量 $e$ を実測した ${ }^{16)}$.

目標載荷履歴は, 部材角 $\theta$ にて $0.02,0.025,0.03,0.04 \mathrm{rad}$ 振 幅により構成する.Fig.1は標準的な載荷履歴であり, 損傷実験では 0.02，0.025 radを2サイクルずつ与えた後, 文献7）における建て起 こしを前提として残留変形がほぼゼロとなるように除荷し, 試験体 を取り外して補修を施す.補修後は載荷装置に再びセットし, 補修 実験として0.02,0.025 radの振幅から載荷を再開し，さらに0.03， $0.04 \mathrm{rad}$ の振幅を 1 ～2サイクルずつ与えて終局状態に至らしめる. なお, 補修実験は, 損傷実験の終了時点での変位計測值を初期值と して再開している.以上の載荷履歴を標準とし, 後述する損傷度に 応じて振幅と繰り返し数を調整した.

\section{3 試験体}

試験体は材長 $1.46 \mathrm{~m}$ の片持ち柱であり, 柱断面, 軸力比 $n$, 損傷 度 $D$, 補修法をパラメータとする計 28 体を用意した。なお, 材長は 試験機の制限によって決定しているが, 柱断面を実大とすれば $3.0 \mathrm{~m}$ 階高の材中央を反曲点とした場合に相当する.試験体一覧をTable 1 に示す.柱は全て冷間成形角形鋼管 (BCR295) とし, 種別FC ${ }^{17)}$ の 200x6 を基準として, 同幅で幅厚比が種別FAの $\square 200 \times 9$ と，異幅 で幅厚比が等しい $\square 300 \times 9$ の計 3 種類を用意した。軸力比 $n$ は，作 用軸力 $N$ を材料試験結果と公称断面に基づく降伏軸力 $N_{y}$ で除した 值とし，0.15，0.30程度の 2 種類を用意した。降伏軸力の值は，補 修計画時のミルシート值と公称断面による計算を意図している.

損傷度 $D$ は, 損傷実験における載荷終了時点での残存耐力 $M_{d}($ 正 負のいずれか小さい方) , および軸力を考慮した全塑性曲げモーメ ントの計算值 $M_{p c}$ を用いて次式のように定義する.

$$
D=1.00-\frac{M_{d}}{M_{p c}} \quad \cdots(1)
$$

寸なわち, 損傷度 $D$ は局部座屈による全塑性曲げモーメントから の耐力低下率を表しており, 損傷実験により $-0.08 \sim+0.63$ の範囲 で変化させた.ここで負の損傷度は, 耐力劣化は見られるものの, 全塑性曲げモーメントを下回らなかったことを表す.なお, 著者ら

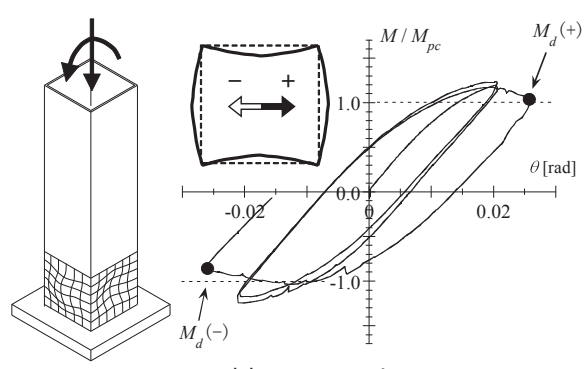

(a) pattern $A$

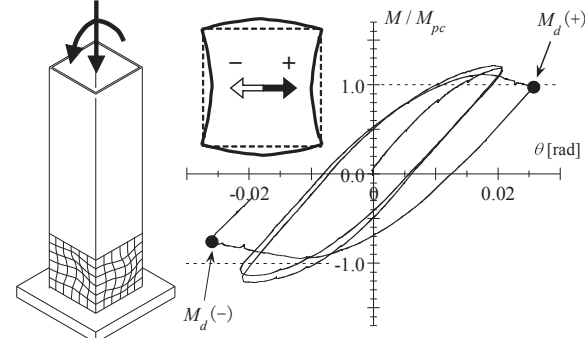

(b) pattern $B$

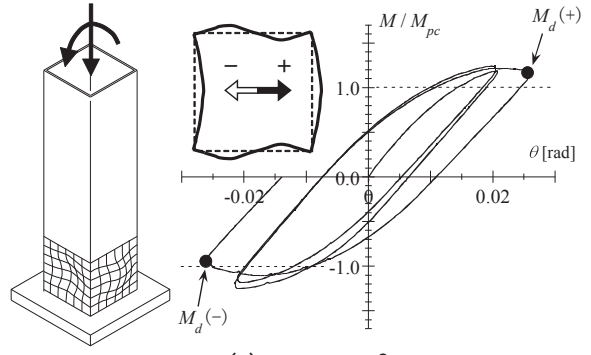

(c) pattern $\mathrm{C}$

Fig. 3 Shapes of local buckling in the "pre-loading experiment" and its damage characteristics 
Table 1 List of test specimens

\begin{tabular}{|c|c|c|c|c|c|c|c|c|c|c|c|c|c|c|c|c|c|}
\hline & \multirow{3}{*}{$\begin{array}{l}\text { Cross } \\
\text { Section }\end{array}$} & \multirow{3}{*}{ Phase } & \multicolumn{4}{|c|}{ Section Characteristics } & \multicolumn{5}{|c|}{ Damage Degree } & \multicolumn{5}{|c|}{ Detail of Cover Plate } \\
\hline & & & & $N$ & $N_{y}$ & $n$ & $M_{p c}$ & $M_{d}(+)$ & $M_{d}(-)$ & $D$ & Buckling & $e$ & $s$ & $t_{r}$ & $h_{r}$ & $b_{r}$ & $d_{r}$ \\
\hline & & & & {$[\mathrm{kN}]$} & {$[\mathrm{kN}]$} & {$[-]$} & {$[\mathrm{kN}-\mathrm{m}]$} & {$[\mathrm{kN}-\mathrm{m}]$} & {$[\mathrm{kN}-\mathrm{m}]$} & {$[-]$} & Pattern & {$[\mathrm{mm}]$} & {$[\mathrm{mm}]$} & {$[\mathrm{mm}]$} & {$[\mathrm{mm}]$} & {$[\mathrm{mm}]$} & {$[\mathrm{mm}]$} \\
\hline \multirow{11}{*}{ RA } & RA-1 & \multirow{7}{*}{$\square 200 \times 6$} & I & 260 & 1641 & 0.16 & 114 & 121 & 94 & 0.17 & A & 10 & \multirow{3}{*}{40} & \multirow{7}{*}{6} & & \multirow{7}{*}{150} & \multirow{7}{*}{150} \\
\hline & RA-2 & & $\mathrm{I}$ & 261 & 1641 & 0.16 & 114 & 112 & 88 & 0.23 & $\mathrm{~B}$ & 10 & & & 200 & & \\
\hline & RA-3 & & I & 261 & 1641 & 0.16 & 114 & 136 & 112 & 0.03 & $\mathrm{C}$ & 10 & & & 200 & & \\
\hline & RA-4 & & I & 261 & 1641 & 0.16 & 114 & 128 & 113 & 0.01 & A & 5 & 60 & & & & \\
\hline & RA-5 & & II & 259 & 1718 & 0.15 & 120 & 123 & 99 & 0.18 & $\mathrm{~A}$ & 11 & \multirow{3}{*}{40} & & 300 & & \\
\hline & RA-6 & & $\mathrm{I}$ & 260 & 1641 & 0.16 & 114 & 133 & 114 & 0.01 & A & 5 & & & 400 & & \\
\hline & RA-7 & & II & 587 & 1718 & 0.34 & 105 & 77 & 91 & 0.26 & $\mathrm{~A}$ & 10 & & & 300 & & \\
\hline & RA-8 & \multirow{2}{*}{$\square 200 \times 9$} & $\mathrm{I}$ & 387 & 2771 & 0.14 & 190 & 209 & 202 & -0.06 & $\mathrm{~A}$ & 5 & \multirow{2}{*}{40} & \multirow{2}{*}{9} & \multirow{2}{*}{200} & \multirow{2}{*}{150} & \multirow{2}{*}{150} \\
\hline & RA-9 & & III & 820 & 2355 & 0.35 & 140 & 150 & 176 & -0.08 & $\mathrm{~A}$ & 16 & & & & & \\
\hline & RA-10 & \multirow{2}{*}{$\square 300 \times 9$} & III & 565 & 3356 & 0.17 & 348 & 348 & 394 & 0.00 & $\mathrm{~A}$ & 14 & \multirow{2}{*}{60} & \multirow[b]{2}{*}{9} & 300 & \multirow[b]{2}{*}{230} & \multirow[b]{2}{*}{230} \\
\hline & RA-11 & & III & 564 & 3356 & 0.17 & 348 & 375 & 399 & -0.08 & $\mathrm{~A}$ & 15 & & & 450 & & \\
\hline \multirow{3}{*}{$\mathrm{RF}$} & RF-1 & & I & 261 & 1641 & 0.16 & 114 & 131 & 116 & -0.01 & $\mathrm{C}$ & 9 & & 6 & 200 & & \\
\hline & RF-2 & $\square 200 \times 6$ & II & 261 & 1718 & 0.15 & 120 & 122 & 104 & 0.13 & $\mathrm{~A}$ & 10 & 40 & 9 & & 150 & \\
\hline & RF-3 & & II & 295 & 1718 & 0.17 & 119 & 75 & 65 & 0.45 & $\mathrm{~A}$ & 21 & & 12 & 300 & & \\
\hline & RW-1 & & II & 260 & 1718 & 0.15 & 120 & 112 & 101 & 0.16 & $\mathrm{~A}$ & 11 & & 6 & & & \\
\hline & RW-2 & & II & 262 & 1718 & 0.15 & 120 & 114 & 104 & 0.13 & $\mathrm{~A}$ & 10 & & 9 & & & \\
\hline & RW-3 & & III & 273 & 1700 & 0.16 & 118 & 92 & 81 & 0.32 & $\mathrm{C}$ & 12 & & 12 & & & \\
\hline & RW-4 & $\square 200 \times 6$ & II & 261 & 1718 & 0.15 & 120 & 91 & 79 & 0.34 & $\mathrm{~A}$ & 20 & 40 & 9 & 300 & & 150 \\
\hline $\mathrm{RW}$ & RW-5 & $\square 200 \times 0$ & II & 262 & 1718 & 0.15 & 120 & 99 & 84 & 0.30 & $\mathrm{~A}$ & 15 & 40 & 12 & 300 & & 150 \\
\hline & RW-6 & & II & 292 & 1718 & 0.17 & 119 & 52 & 63 & 0.56 & $\mathrm{~A}$ & 23 & & 6 & & & \\
\hline & RW-7 & & III & 272 & 1700 & 0.16 & 119 & 56 & 44 & 0.63 & $\mathrm{~A}$ & 27 & & & & & \\
\hline & RW-8 & & II & 589 & 1718 & 0.34 & 105 & 56 & 80 & 0.46 & $\mathrm{~A}$ & 13 & & 12 & & & \\
\hline & RW-9 & $\square 300 \times 9$ & III & 564 & 3356 & 0.17 & 348 & 269 & 332 & 0.23 & $\mathrm{~A}$ & 20 & 60 & 12 & 300 & & 230 \\
\hline & NR-1 & $\square 200 \times 6$ & $\mathrm{I}$ & 261 & 1641 & 0.16 & 114 & & & & A & & & & & & \\
\hline & NR-2 & $200 \times 0$ & II & 590 & 1718 & 0.34 & 105 & & & & A & & & & & & \\
\hline NR & NR-3 & $\sqcap 200 \times 9$ & I & 385 & 2771 & 0.14 & 190 & & & & $\mathrm{~A}$ & & & & & & \\
\hline & NR-4 & $\square 200 \times Y$ & III & 821 & 2355 & 0.35 & 140 & & & & A & & & & & & \\
\hline & NR-5 & $\square 300 \times 9$ & III & 564 & 3356 & 0.17 & 348 & & & & $\mathrm{~A}$ & & & & & & \\
\hline
\end{tabular}

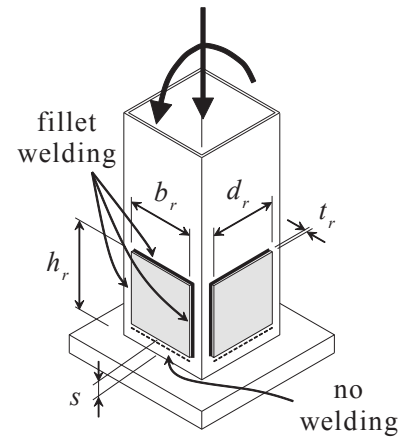

(a) RA series

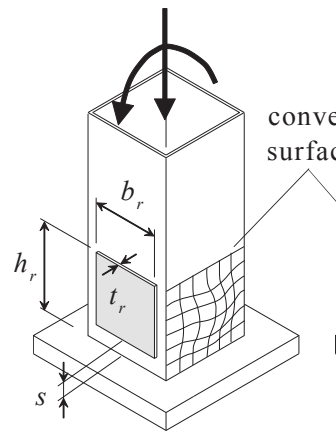

(b) RF series

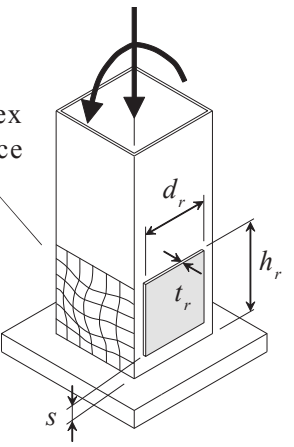

(c) RW series

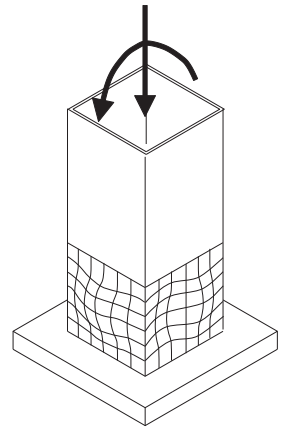

(d) NR series

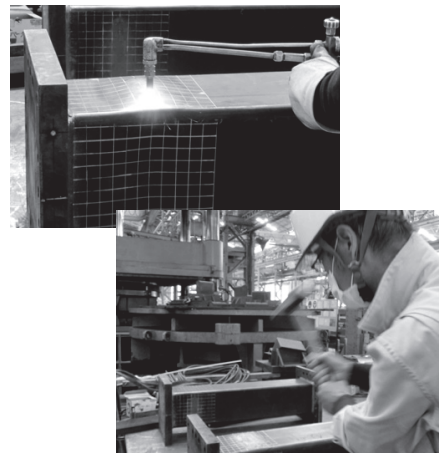

Heating and hit to make it flat

Fig. 4 Seismic repair by cover plates (series of the repaired specimen)

は局部座屈によって生じる柱フランジの面外変形を実測することで 残存耐力 $M_{d} / M_{p c}$ を推定する方法を提案しており ${ }^{16)}$, 復旧計画の段 階における損傷度 $D$ の推定は十分に可能であると考えている.

損傷実験における局部座屈変形の分類とそれぞれの履歴挙動の一 例をFig. 3 に示す. 図の縦軸は柱脚部の曲げモーメント $M$ を, 軸力 を考慮した全塑性曲げモーメント $M_{p c}$ の計算值で除した值であり, 横軸は制御に用いた部材角 $\theta$ である. 局部座屈変形の凹凸は, 損傷 実験では $\mathrm{A} \sim \mathrm{C}$ の 3 パターンが確認されたが, 試験体の大部分は, フランジが凸,ウェブが凹となるAパターンであった（Table 1). ま た, 同じ載荷履歴であっても局部座屈変形の凹凸によって耐力劣化 の程度が異なることが分かる。

\section{4 カバープレートによる被災後補修}

\section{4.1 補修の概要}

本節では, 最後のパラメータである補修法について説明する.本
論文で採用した被災後補修の概要をFig.4に示す.局部座屈が生じ た角形鋼管柱へのカバープレート補修は, 文献7)に記載されている 方法に準じて行う。手順としては，まず局部座屈の凸部を表面が $700^{\circ} \mathrm{C}$ 程度になるまで熱して赤らめ, ハンマーで吒いてなる心゙く平 滑になるように矯正する (Fig.4右端).その後, 凹部はそのままとし て補修板を隅肉溶接にて取り付ける.ただし, 凹部の変形が $20 \mathrm{~mm}$ 以上と大きく,溶接にて隙間を埋めきれない場合には, 凹部の大き な変形部を避けた断続溶接とした(試験体RF-3, RW-6, RW-7, RW9). なお, 隅肉溶接については, いずれも補修板の上面と両側面の 3 辺のみに行い, サイズは補修板の板厚の 0.7 倍以上とした.

試験体は, フランジ・ウェブの4面全てをカバープレート補修し たRAシリーズ(Fig.4 (a)) と,フランジあるいはウェブのいずれか 2面にカバープレート補修したRF, RWシリーズ (Fig.4（b)，(c)）に 大別される.また, 終局状態における補修効果の検証として無補修 
Table 2 Material properties according to JIS-1A

\begin{tabular}{|c|c|c|c|c|c|c|}
\hline & & Phase & $\begin{array}{c}\sigma_{\mathrm{y}} \\
{\left[\mathrm{N} / \mathrm{mm}^{2}\right]} \\
\end{array}$ & $\begin{array}{c}\sigma_{\mathrm{u}} \\
{\left[\mathrm{N} / \mathrm{mm}^{2}\right]} \\
\end{array}$ & $\begin{array}{l}Y . R . \\
{[\%]} \\
\end{array}$ & $\begin{array}{c}\varepsilon_{\mathrm{u}} \\
{[\%]}\end{array}$ \\
\hline \multirow{3}{*}{$\square 200 \times 6$} & \multirow{6}{*}{ BCR295 } & $\mathrm{I}$ & 362 & 445 & 81 & 20 \\
\hline & & II & 379 & 449 & 84 & 24 \\
\hline & & III & 375 & 433 & 87 & 20 \\
\hline \multirow{2}{*}{$\square 200 \times 9$} & & I & 420 & 457 & 92 & 22 \\
\hline & & II & 357 & 432 & 83 & 23 \\
\hline$\square 300 \mathrm{x} 9$ & & III & 329 & 421 & 78 & 26 \\
\hline PL-6 & \multirow{3}{*}{ SS 400} & I-III & 292 & 398 & 73 & 28 \\
\hline PL-9 & & I-III & 346 & 458 & 76 & 26 \\
\hline PL-12 & & I-III & 309 & 455 & 68 & 30 \\
\hline
\end{tabular}

$※ \sigma_{y}(\mathrm{BCR} 295)$ is $0.2 \%$ offset strength

の NRシリーズ $(F i g .4(d))$ も用意した。ここで2面補修の RF, RW シリーズは, 凸部の矯正を避け, 凹部のみをカバープレート補修す ることを想定した試験体である.前述したように本実験における局 部座屈変形の多くはAタイプ (Fig.3 (a))であったため, 補修実験時 に試験体を90度回転させてフランジとウェブを入れ替えて設置する ことでRFシリーズを再現している.これは補修後に損傷時と卓越 する地震応答の方向が異なることを想定した試験体とも位置づけら れる.4面補修が適用可能な凸部を矯正できる範囲は, 局部座屈変 形 $e / B^{16)}(e$ : 局部座屈による面外変形, $B$ : 柱幅 $)$ でおおよそ 0.05 以 下を目安とした. なお, 本実験における凸部の矯正から補修板の溶 接までの作業は, 全て工場内にて下向き姿勢で行っている.

\section{4.2 補修板の寸法}

カバープレートを構成する補修板の寸法は, 厚さ $: t_{r}$, ベースプ レートから補修板上面までの高さ $: h_{r}$, ベースプレートから補修板 下面までの隙間 : $s$, および幅 $: b_{r}, d_{r}$ によって決まる。このうち, 隙間: $s$ は, H形断面柱に対する日の字断面補修の実験結果 ${ }^{4)}$ を映 し, 復旧技術指針7)では25〜 40mmを推奨している. 本研究ではこ れに基づき，隙間 $: s$ を $\square 200$ では $40 \mathrm{~mm}, \square 300$ では $60 \mathrm{~mm}$ とし た.ただし,この規定の角形鋼管柱に対する適用を検証するために $\square 200$ の柱で $s=60 \mathrm{~mm}$ とした試験体（RA-4）も用意した.また, 幅: $b_{r}, d_{r}$ は, 隅肉溶接が柱断面 $\mathrm{R}$ 部に干渉しないように $\square 200$ では $150 \mathrm{~mm}, \square 300$ では $230 \mathrm{~mm}$ とした.したがって, 実質的なパラメー 夕は, 補修板の厚さ $: t_{r}$ と高さ $: h_{r}$ である. 厚さ $: t_{r}$ は, 4 面補修で は鋼管厚と同厚とし, 2 面補修の場合には 1 ～2 サイズアップの板 厚の適用を検討した。一方の高さ: $h_{r}$ は, 局部座屈領域を覆う必要 があり, 座屈半波長が鋼管幅の 0.8 倍程度となる既往研究の知見 ${ }^{18)}$ を参考に，鋼管幅の $1.0 ， 1.5,2.0$ 倍を検討した.

本実験は 3 期 $(\mathrm{I} \sim \mathrm{III})$ にわたって実施したため, 角形鋼管につい ては最大 3 種類のロットを用いた。一方の補修板については, 3 期 (I〜III) にわたって同一ロットの鋼材を用意した. 使用鋼材につい て, JIS-1A号引張試験片による材料試験結果をTable 2にまとめる.

\section{3. 実験結果と考察}

\section{1 履歴挙動における各パラメータの影響}

実験より得られた履歴挙動を, パラメータごとの比較としてFig.5 に示し, 実験結果の一覧を Table 3 にまとめる. 図は繰り返し履歴 曲線から抽出した拡張骨格曲線19)であり, 正負荷重下の拡張骨格曲 線のうち, 最大耐力の大きな正側の結果を示している.また, 比較 対象となる無補修 (RNシリーズ)の結果を灰色線にて示し, 補修実 験の結果はそれぞれの損傷度 $D$ で無補修の履歴曲線と交わるように 横軸の変形量をオフセットしている.すなわち, 損傷実験では無補
修の拡張骨格曲線においてそれぞれの損傷度 $D$ (の印) まで耐力が低 下し, その位置から除荷して補修し, 補修実験の再載荷を行ったも のとして実験結果を表現している.これに加え,フランジ正面から 撮影した最終破壊状況をPhoto 2 に例示している。ここで, 局部座 屈が補修材上部にて発生した場合を $\mathrm{T}$ (Photo 2 (a) 左), 補修材下部 にて発生した場合をB (Photo 2 (a) 右), 補修材内にて発生した場合 をM (Photo 2(b) (c)) と呼び, 分類結果をTable3 右端に記載する.

\subsubsection{4 面補修の補修効果に対する各パラメータの影響}

\section{【損傷時における局部座屈変形の凹凸の影響】}

まず,4面補修(RAシリーズ)を対象とし, 損傷実験で観察された 局部座屈変形の凹凸の影響について検討する (Fig.5 (a)).いずれの 試験体も耐力は残存耐力から回復し, 最大耐力は初期損傷時より 3 〜 9\%程度上昇している. 2.3 節で示したように同じ載荷履歴でも凹 凸によって損傷度はばらついたが, 補修後の履歴曲線はほぼ同様で ある。これらの試験体では補修材高さ $h_{r}$ を鋼管幅と等しい $200 \mathrm{~mm}$ としており,いずれも補修板上部にて局部座屈が発生した ( T, Photo 2 (a) 左).したがって, 損傷時と異なる断面で最大耐力が決まった ことも要因の一つではあるが, 初期損傷時における凹凸の違いが補 修効果に及ぼす影響は小さいと言える.

\section{【補修材下部の隙間, および補修高さの影響】}

次いで, 補修材下部の隙間 $s$ の影響 $(F i g .5(\mathrm{~b}))$ ), および補修高さ $h_{r}$ の影響 $(F i g .5(\mathrm{c}))$ について検討する.両図ではほぼ等しい損傷度 の試験体にて隙間 $s$, 補修高さ $h_{r}$ の違いをそれぞれ比較している.

まず隙間の違い (Fig.5 (b)) についてみると, 補修後の履歴曲線に 違いは見られないが, 隙間を $60 \mathrm{~mm}$ に広げることで局部座屈の発生 位置が補修材下部(B)へと変化した。また， $\square 200$ における補修高 さの違い(Fig.5 (c) 左)においても, 補修高さを $300 \mathrm{~mm}$ 以上とするこ とで局部座屈の発生位置が補修板下部 (Photo 2 (a) 右) となった.た だし,こちらでは局部座屈の発生位置が変わることで履歴曲線の耐 力劣化勾配が緩やかになっていることが分かる.これは, 写真にお いて局部座屈領域 (座屈半波長 ${ }^{18}$ ) ) が短いことから, 補修板下部に発 生した局部座屈変形が補修材に拘束されたために耐力劣化勾配が緩 やかになったものと考えられる.換言すれば, 隙間を広げて補修材 下部に局部座屈が生じる場合(RA-4) には, 局部座屈変形に対する補 修材の拘束は小さかったと言える.H形鋼柱に対する日の字断面補 修)においては, 広い隙間で生じた局部座屈による耐力劣化は著し いことが報告されている.しかし，60mmの隙間を標準とした $\square 300$ (Fig.5 (c) 右) では, $\square 200$ と同様の緩やかな耐力劣化勾配が得られ ている.したがって, 角形鋼管柱へのカバープレート補修における 隙間 $s$ は, 鋼管幅に応じて決める心゙きであり, $\square 200$ では $40 \mathrm{~mm}$ 程 度, $\square 300$ では $60 \mathrm{~mm}$ 程度としておけば良いと言える。

一方, $\square 300$ における補修高さの違い（Fig.5 (c) 右）についてみる と, 図中では $\square 200$ と同様に補修高さを鋼管幅の 1.0 倍, 1.5 倍とし た場合を比較しているが,いずれも局部座屈は補修板下部 (B)に発 生し, 耐力劣化勾配も緩やかである.したがって, 補修高さについ ては, 鋼管幅によらず, せん断スパンに応じた高さによって局部座 屈の発生位置が決まるものと考えられる.この点については4.1節 において再度検討する。

\section{【軸力比の影響】}

次いで, 軸力比 $n$ の影響について検討する $(F i g .5(\mathrm{~d}))$. 補修後は, 

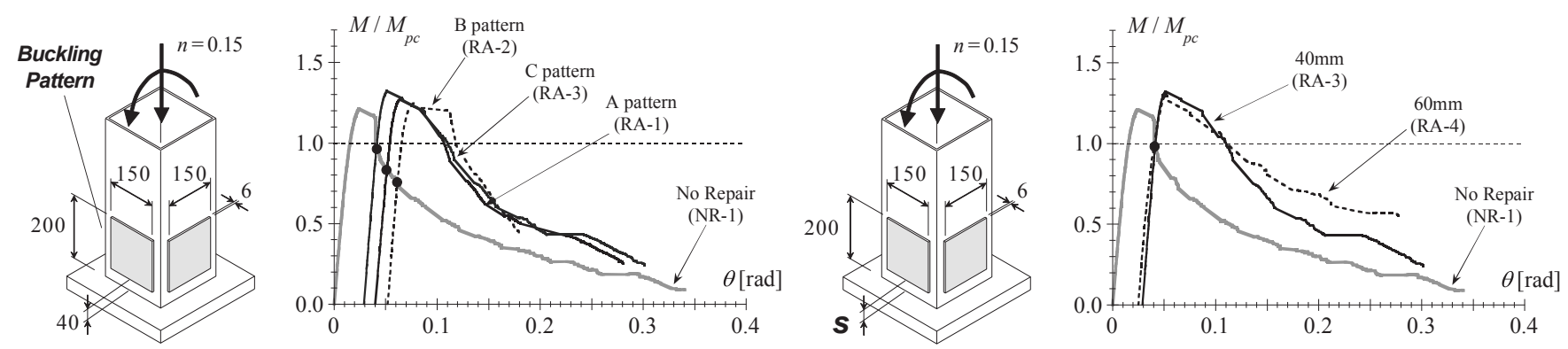

(a) Effect of "buckling pattern" in the pre-loading

(b) Effect of gap under the repairing plate: $s$
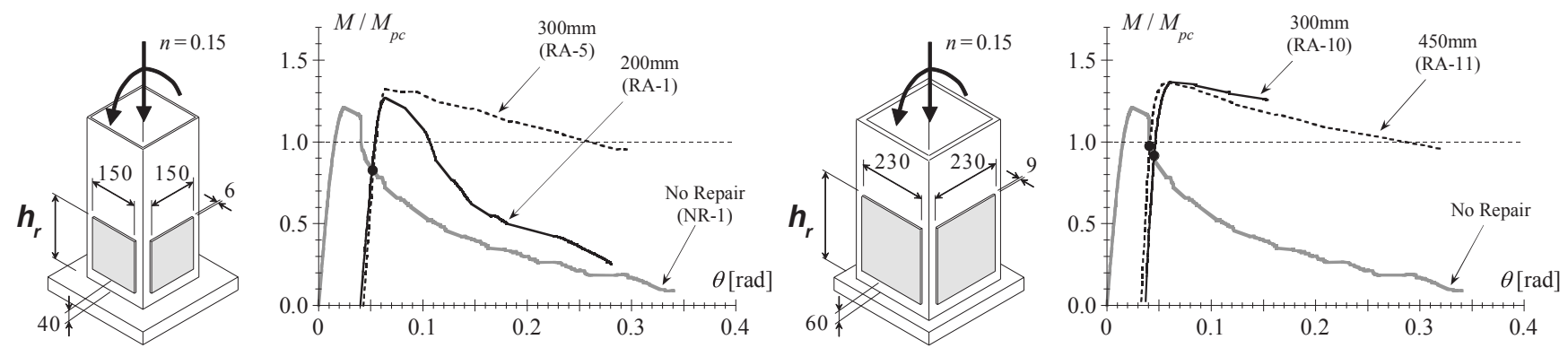

(c) Effect of the repairing height: $h_{r}$ (left: $\square 200 \times 6$, right: $\square 300 \times 9$ )
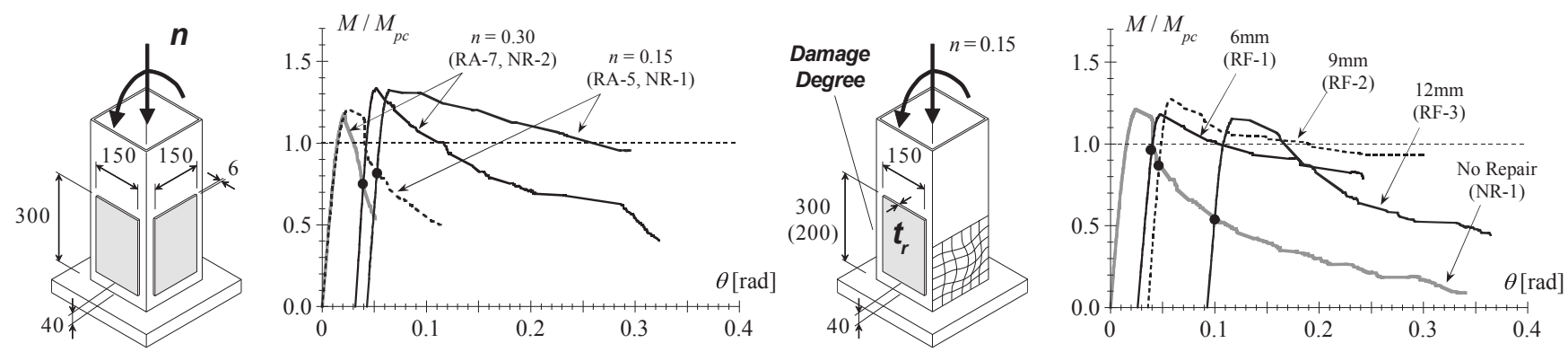

(d) Effect of axial force: $n$

(e) Effect of thickness of the repairing plate: $t_{r}$ for RF series

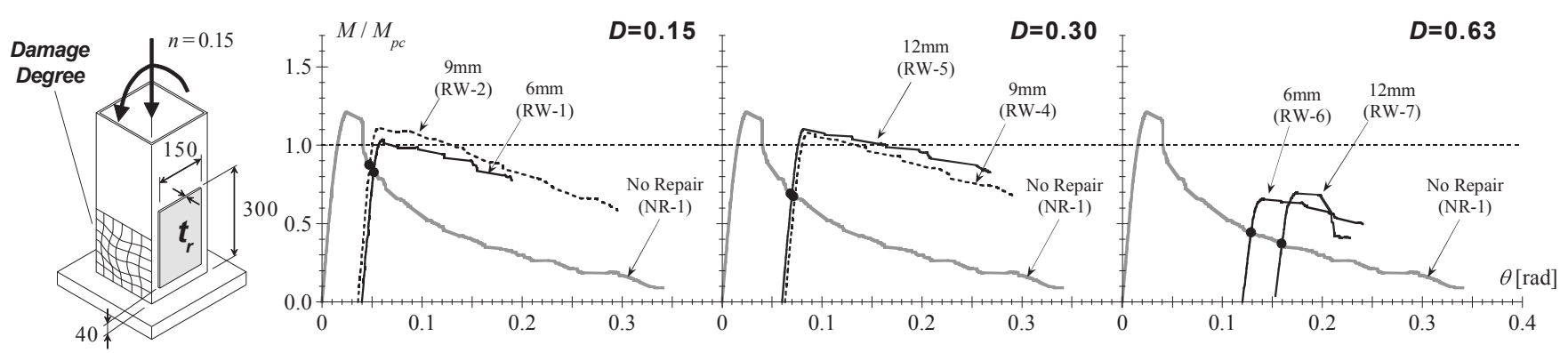

(f) Effect of thickness of the repairing plate: $t_{r}$ at the various "damage degree" for RW series
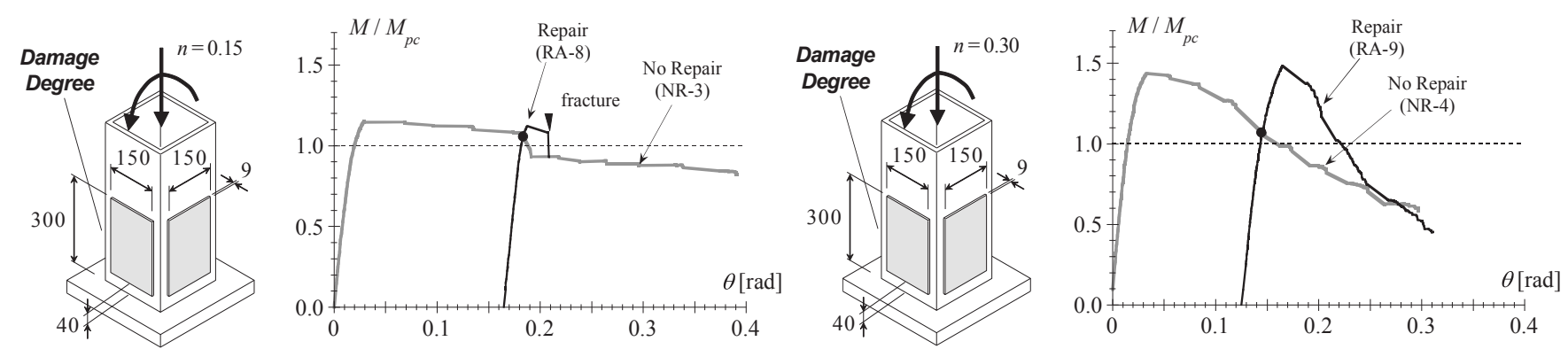

(g) Effect of axial force: $n$ for FA rank column ( $\square 200 \times 9$ )

Fig. 5 Skeleton curves of the repaired specimens and effects of the selected parameters 
Table 3 List of test results

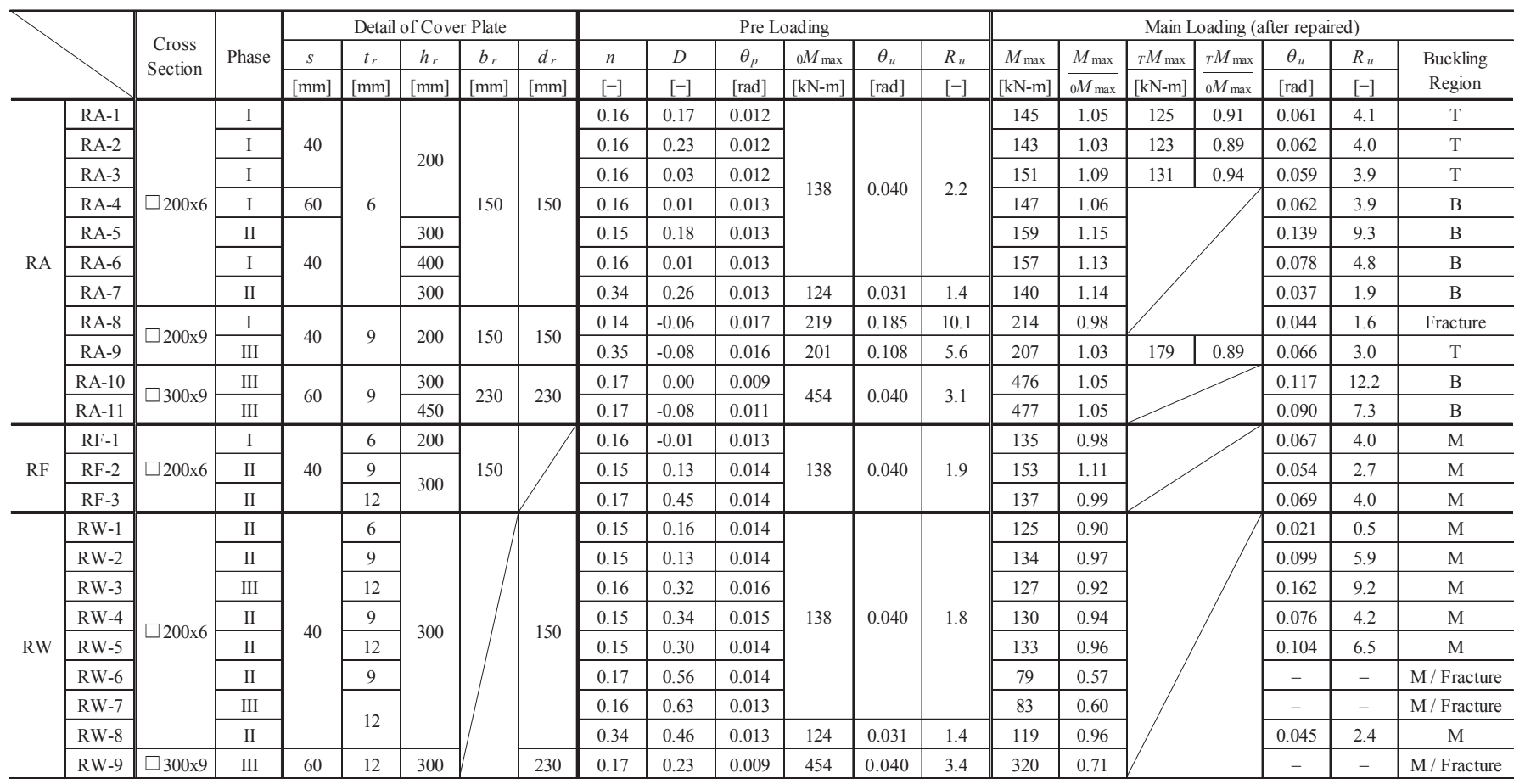

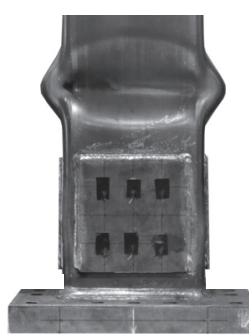

(a) RA series

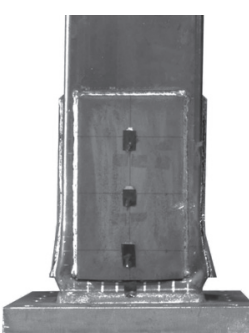

(a) RA series

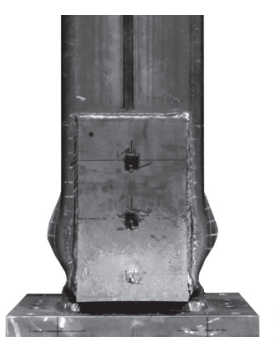

(b) RF series

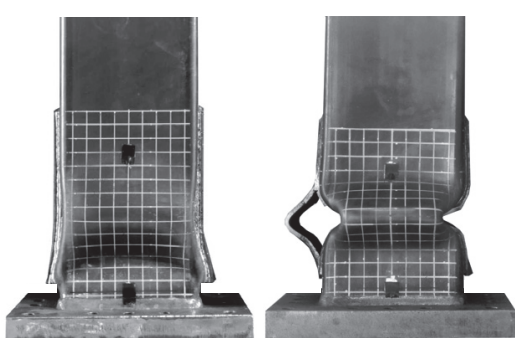

(c) RW series

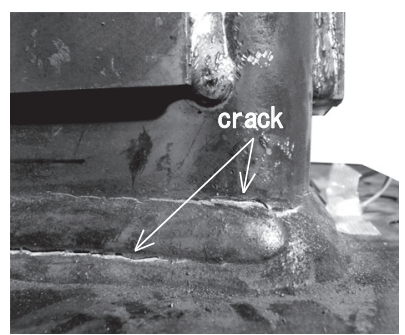

(d) crack at the welding

Photo 2 Overview in front of column flange ater testing (definition of the buckling region) and crack at the welding

軸力比が 0.30 と大きい場合も耐力は残存耐力から回復し, 最大耐力 については軸力比によらず, 初期損傷時から $15 \%$ 程度の上昇が確認 できる.また, 耐力劣化そのものは軸力比 0.30 の方が急勾配ではあ るが, 補修の有無について比較すれば,いずれも無補修に対して耐 力劣化勾配は緩やかになっていることが分かる.したがって, 軸力 比 0.15 と 0.30 の違いであれば, 軸力比の大きさが補修効果に及ぼ す影響は小さいと言える.

\subsubsection{2 面補修(フランジ)の補修効果に対する損傷度の影響}

2 面補修では, 前項までの結果を踏まえ, 補修高さ $h_{r}$ を $300 \mathrm{~mm}$, 隙間 $s$ を $40 \mathrm{~mm}(\square 300$ では $60 \mathrm{~mm})$ を基本としている.ここでは，ま ずフランジのみを補修したRFシリーズについて, 損傷度 $D$ と補修 板の厚さ $t_{r}$ の影響を検討する $(F i g .5(\mathrm{e}))$. いずれの試験体も耐力は 残存耐力から回復し, 最大耐力は初期損傷時と同程度以上にまで回 復している. 局部座屈は4面補修とは異なり, フランジでは補修板 下部 (B)よりやや上方に, ウェブでは初期損傷時とほぼ同位置に発 生した $(\mathrm{M}$, Photo2 (b)).

損傷度がほぼ等しい試験体RF-1 とRF-2 とて補修板の厚さ $t_{r}$ の違 い $(6 \mathrm{~mm}$ vs $9 \mathrm{~mm})$ を比較すると, 補修板の厚い方が最大耐力が大き いことが分かる. また, 耐力劣化勾配は4面補修と同様に無補修に 比べて緩やかになっており, 曲げモーメントへの寄与が大きいフラ
ンジに対する局部座屈変形の拘束効果が表れている.一方, 損傷度 の大きな試験体 RF-3では, 厚さ $12 \mathrm{~mm}$ の補修板を用いているにも 関わらず, 最大耐力は初期損傷時とほぼ同程度までしか回復してい ない.これは凹部の局部座屈変形が $20 \mathrm{~mm}$ 以上となり, 補修板を断 続溶接にて取り付けたことが影響しているものと考えられる.

\subsubsection{2 面補修 (ウェブ)の補修効果に対する損傷度の影響}

次いで, ウェブのみを補修した RWシリーズについて, 損傷度 $D$ と補修板の厚さ $t_{r}$ の影響を検討する $(F i g .5(\mathrm{f}))$. いずれの試験体も 耐力は残存耐力から回復しているが, 最大耐力は初期損傷時より小 さい. 局部座屈の多くは, RFシリーズとは反対に, ウェブでは補修 板下部 (B)よりやや上方に, フランジでは初期損傷時とほぼ同位置 に発生した ( M, Photo2 (c) 左)。損傷度の影響をみると, 損傷度が $0.15,0.30$ 程度であれば, 補修後の最大耐力は全塑性曲げモーメン 卜にまで達し, 耐力劣化勾配も緩やかとなっており，4面補修と同 等の補修効果が得られることが分かる (Fig.5 (f) 左・中).一方, 損 傷度が $0.56,0.65$ の試験体 (Fig.5 (f) 右) は，2.4節で述べたように 凹部の変形が大きいために補修板を断続溶接にて取り付けており, 局部座屈変形の進展に伴って溶接を中断した部分から溶接部にき裂 が発生し, 最終的には補修板が柱ウェブから分離した (Photo2 (c) 右).このため, 補修後の最大耐力は全塑性曲げモーメントにまで 


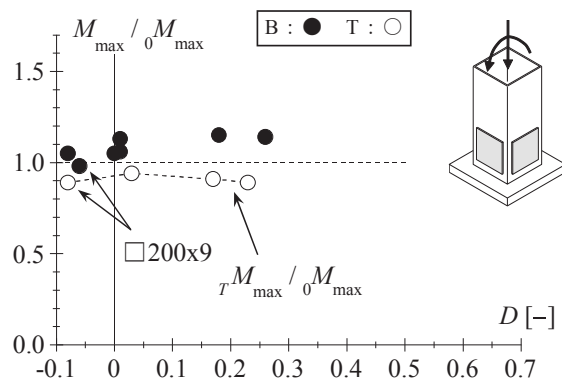

(a) RA series

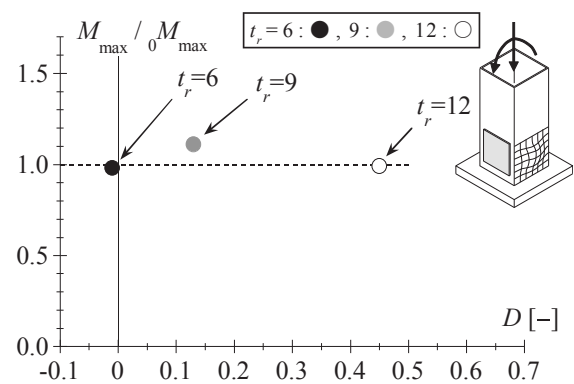

(b) RF series

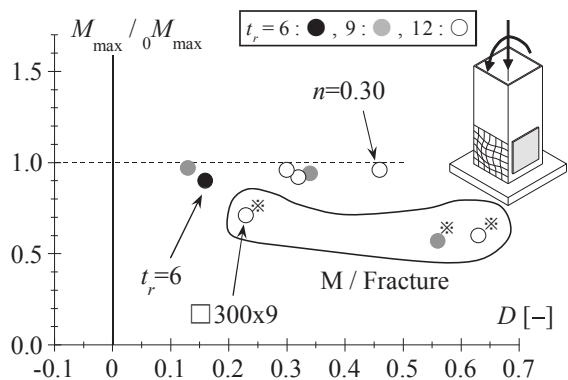

(c) RW series

Fig. 6 Effects of seismic repair on the maximum strength

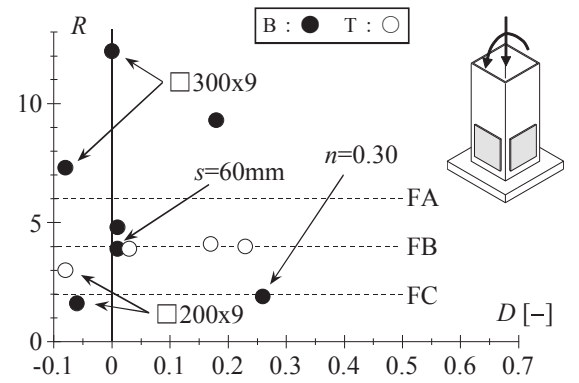

(a) RA series

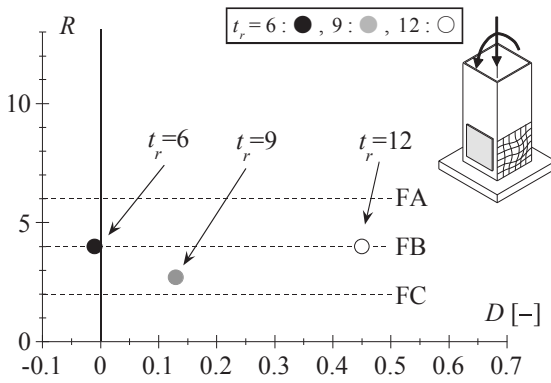

(b) RF series

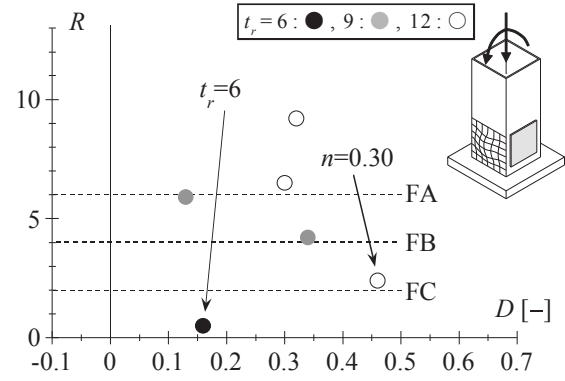

(c) RW series

Fig. 7 Effects of seismic repair on the plastic rotation capacity

到達せず, 4面補修と同等の補修効果は得られなかった。

補修板の厚さ $t_{r}$ の違いについては, 損傷度が 0.15 では補修板の厚 い方 $(6 \mathrm{~mm} \rightarrow 9 \mathrm{~mm})$ が $7 \%$ ほど最大耐力が大きい結果も得られてい るが, 他の損傷度では補修板の厚さによる違いは見られない.これ は, ウェブへの補修は, 曲げモーメントへの寄与が大きなフランジ の局部座屈変形を間接的に抑える効果しかないためである.

\subsection{4 幅厚比の小さな断面に対する補修効果}

最後に, 種別 FAの $\square 200 \times 9$ 断面に対する補修効果を検討する (Fig.5 ( g) ) . 補修後は, 耐力は残存耐力から回復し, 最大耐力も初 期損傷時と同程度まで回復している. しかし, 最大耐力到達後の塑 性変形能力は, 無補修に比べて低下した. 特に軸力比 0.15 では明瞭 な局部座屈の発生は確認されず, 補修板下部に塑性変形が集中し た. 実験中は早い段階でベースプレートとの溶接部にき裂が確認さ れ, 最終的にはき裂が幅方向に進展することで破断に至り, 耐力を 喪失した (Photo2 (d)). 一方の軸力比 0.30 では, 局部座屈が補修板 上部 $(\mathrm{T})$ に発生したが, 耐力劣化は無補修より急勾配であった。

これら幅厚比の小さな断面は, 特に軸力比が小さい場合に局部座 屈の発生が遅く, また発生後の耐力劣化勾配も緩やかであるため, 損傷実験で大きな変位振幅まで載荷を行っている.したがって, 損 傷時における部材端部の累積塑性変形量が非常に大きいため, 溶接 部の破断に至ったものと考えられる.幅厚比の小さな断面, いわゆ る種別FAに分類されるような断面については, 局部座屈変形だけ で損傷状態を推定できず, 部材端部の累積塑性変形量の評価法とそ れを考慮した補修法が必要であると言える.

\section{2 補修後の最大耐力}

ここでは, 3.1 節における実験結果のうち, 補修後の最大耐力に ついて整理する. 補修後の最大耐力 $M_{\text {max }}$ を, 初期損傷時の最大耐力 ${ }_{0} M_{\text {max }}$ に対する比 $M_{\text {max }}{ }_{0} M_{\text {max }}$ として表し, 損傷度 $D$ との関係を Fig.6 に示寸. 図中, 4面補修であるRAシリーズ (Fig.6 (a)) では局部座屈 の発生位置の違いをプロットの種類 $(\mathrm{B}: \bigcirc, \mathrm{T}: \bigcirc)$ によ表し, 2
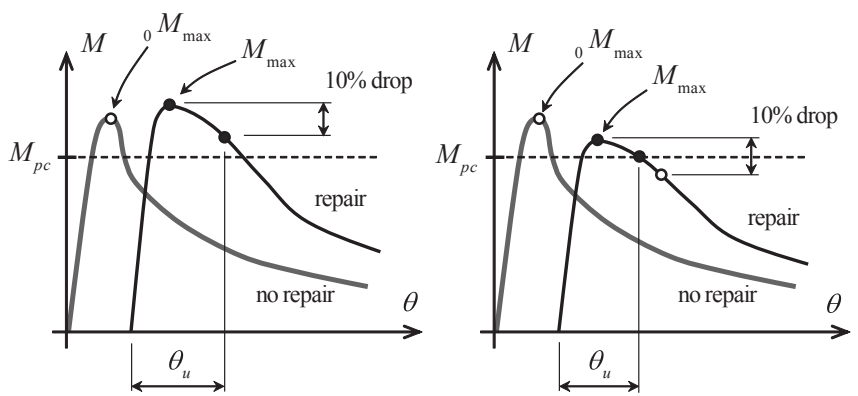

Fig. 8 Definition of the plastic rotation capacity

面補修のRF, RWシリーズ (Fig.6 (b)，（c）) では補修板の厚さの違い をプロットの種類 $\left(t_{r}=6: \bigcirc, 9: \bigcirc, 12: \bigcirc\right)$ にり表している. な お, 補修板上部で局部座屈が発生した場合には, 次式より得られる 補修板上部における最大耐力 $T_{T} M_{\text {max }}$ を用いた耐力比 $M_{T} M_{\text {max }}{ }_{0} M_{\text {max }}$ をプ ロットしている. また, 具体的な数值は Table 3 に記載している.

$$
\begin{aligned}
& { }_{T} M_{\text {max }}=M_{\text {max }} \cdot\left(1-\frac{h_{r}}{H}\right) \quad \cdots(2) \\
& \text { ここで, } H \text { : 試験体材長 }(=1460 \mathrm{~mm})
\end{aligned}
$$

4面補修 (Fig.6 (a)) における最大耐力 $M_{\text {max }}$ の初期損傷時に対する 上昇率は, 局部座屈が補修板下部に発生した場合 (B :

には 1.15 あるいは1.05程度であった。具体的には隙間 $s$ が $40 \mathrm{~mm}$ の場合に 1.15 程度, $60 \mathrm{~mm}$ の場合に 1.05 程度となった。これは3.1.1 項で述べた ように局部座屈変形が補修板によって拘束されたためであると考え られ, 具体的な上昇率も補修材下部の隙間により差異が見られた. 一方, 補修板上部に発生した場合 $(\mathrm{T}: \bigcirc)$ の上昇率は1.03〜1.09で あり, 補修板上部における最大耐力の換算值 ${ }_{T} M_{\text {max }}$ では $0.89 \sim 0.94$ となり, 平均して $9 \%$ ぼ初期損傷時より最大耐力が低くなってい る.これは柱脚端 (エンドプレート)に比べると補修板による拘束が 弱いためであると考えられる.すなわち, 初期損傷時の柱脚端と補 修後の補修板上部におけるそれぞれの最大耐力を比較した場合, 拘 
束力の差に起因して両者の耐力評価断面から座屈耐力規定点までの 距離が異なるためである.なお, 実際に補修板上部にて発生した局 部座屈の実測結果では, 座屈発生領域までの距離が柱脚端で発生す る場合に比べてやや短い傾向が確認できている.

次いで, 2 面補修についてみると, RFシリーズ (Fig.6(b))では, 試験体RF-2 $\left(t_{r}=9 \mathrm{~mm}\right)$ に $10 \%$ の上昇が見られるが, 他は初期損傷 時とほぼ同等である。一方, RWシリーズ $(F i g .6(\mathrm{c}))$ では, 凹部に 連続溶接にて補修板を取り付けられ ( $e$ が $20 \mathrm{~mm}$ 未満), かつ損傷度 が 0.46 以下であれば上昇率は $0.90 \sim 0.97$ となり, 平均して $6 \%$ ほ ど初期損傷時より最大耐力が低くなっている. 2 面補修では 4 面補 修に比べて局部座屈変形への拘束が弱いものの, いずれも柱脚端に おいて最大耐力を評価したため, 初期損傷時とほぼ同程度の最大耐 力が得られたものと考えられる.

\section{3 補修後の塑性変形能力}

引き続き, 補修後の塑性変形能力について整理する.最大耐力と 同様の表現を用いて塑性変形能力をFig.7に示す. 図中の塑性変形 能力の指標は, 次式で表される塑性変形倍率 $R$ を用いる.

$$
R=\frac{\theta_{u}}{\theta_{p}}-1
$$

ここで, $\theta_{u}$ は最大耐力の $90 \%$, あるいは耐力が軸力を考慮した全 塑性曲げモーメントにまで低下した時点の部材角 ${ }^{20)}$ (Fig.8)であり, 最大耐力を得た正載荷時の值をとる.ただし, 補修後の最大耐力が 全塑性曲げモーメントに到達しない場合はRを評価しない.ここで $\theta_{p}$ は弾性剛性の実験值を用いて得た全塑性曲げモーメント時の弾性 部材角である.また, 図中には, 部材種別の必要值の参考21) (FA : $6, \mathrm{FB}: 4, \mathrm{FC}: 2)$ を破線にて示している.

4面補修 (Fig.7 (a)) における塑性変形能力 $R$ は, 種別 FCの断面に おいて局部座屈が補修板下部に発生した場合 $(\mathrm{B}: \mathbf{O})$ には, 隙間を 広げた試験体RA-4 $(s=60)$ と軸力比が大きい試験体RA-7 $(n=0.30)$ を除けば, $R=4.8$ 以上の塑性変形能力を有している.隙間を広げた 試験体RA-4 と軸力比が大きい試験体RA-7の $R$ は, それぞれ3.9 と 1.9 であり, 他と比べると塑性変形能力は低いが, 初期損傷時 $(2.2$, 1.4）と比べると塑性変形能力は向上している. 一方, 種別 FCの断 面において局部座屈が補修板上部に発生した場合 $(\mathrm{T}: \bigcirc)$ では, い ずれも $R=4.0$ 程度であり, 補修板下部に局部座屈が発生した場合と 比べると塑性変形能力はやや低い傾向にある.これはH形断面柱一 の補強実験22)などでも報告されており,補修板上部では局部座屈変形 の拘束が柱脚端に比べて相対的に弱いこと, また同じ柱の部材角に 対しても補修板上部では塑性ヒンジに要求される回転変形が部材端 の場合に比べて大きくなることが要因の一つであると考えられる.

種別FAの断面 ( $\square 200 \times 9)$ について, 初期損傷時に対して塑性 変形能力が低下している.特に溶接部の破断に至った試験体RA-4 は $R=1.6$ であり, 種別 $\mathrm{FC} の$ 必要值を下回っているため, 塑性変形 能力の観点では, カバープレート補修の効果は期待できない.

次いで, 2 面補修についてみると, RFシリーズ(Fig.7 (b))では, 初期損傷時に比べて塑性変形能力が向上しており, 試験体RF-2が $R$ $=2.7$ と僅かに小さいが, 他は $R=4.0$ に達している.一方, RWシリー ズ (Fig.7 (c)) では, 損傷度 0.46 以下, 軸力比 0.15 の $\square 200 \times 6$ 断面 に対しては, 補修板を鋼管厚より 1 サイズ以上厚くしておけば, $R$ $=4.0$ 以上の塑性変形能力を付与できていることが分かる.

\section{4. カバープレートによる角形鋼管柱の被災後補修法}

最後に, 前章までに得られた実験結果をまとめ, 角形鋼管柱への カバープレート補修法を整理する.なお, 現時点では, 局部座屈に よる耐力劣化が顕著な断面(種別 FC, 幅厚比 33.3) が適用対象と なっており, 更なる実験データの蓄積が必要である.また, 本実験 で行った幅厚比の小さな断面(種別FA, 幅厚比22.2)については適 用範囲外とする.

\section{14 面補修を用いた被災後補修法}

\subsubsection{4 面補修の適用範囲と補修板の仕様}

この補修法は, 損傷した角形鋼管柱における局部座屈変形 $e / B$ が 0.05 以下 (損傷度 $D$ として 0.26 以下) の場合に適用できる.この適 用範囲は, 本実験において凸部表面を熱した後にハンマーで吒いて 平滑になるように矯正できた実績に基づいて定めたものである.な お, 文献15)における矯正実績も同程度である。

カバープレートを構成する補修板は, 厚さ $t_{r}$ を鋼管厚と同厚にす るとともに, 幅 $b_{r}, d_{r}$ を柱断面 $\mathrm{R}$ 部に溶接が干涉しない範囲とし, 柱部材端部との間に隙間 $s(\square 200$ では $40 \mathrm{~mm}, \square 300$ では $60 \mathrm{~mm})$ を 設けて隅肉溶接にて取り付ける.隅肉溶接は, 柱部材端部側の辺を 除く 3 辺について行い, サイズを補修板の板厚の 0.7 倍以上とする.

一方, 補修高さ $h_{r}$ については, 少なくとも損傷時の局部座屈領域 より高くしておく必要がある.また,この高さに応じて補修後の局 部座屈の発生位置と補修効果が変化する.ここで最大耐力が局部座 屈の発生によって決定づけられ,かつ補修板を取り付けた断面の而 力は元断面よりも大きいと仮定すれば, 補修板上部と下部が同時に 最大耐力に達する補修高さ ${ }_{T B} h_{r}$ は, 次式により表せる.

$$
\frac{M_{\max }}{H}=\frac{{ }_{T} M_{\max }}{H-{ }_{T B} h_{r}}
$$

補修後に局部座屈が発生する際の柱脚部と補修板上部における最 大耐力 $M_{\text {max }},{ }_{T} M_{\text {max }}$ は, 3.2節にて初期損傷時の最大耐力 ${ }_{0} M_{\text {max }}$ に対す る比として整理している (Fig.6 (a)). 初期損傷時からの上昇率をそ れぞれ ${ }_{B} \xi,{ }_{T} \xi$ と置けば, (4) 式を次式のように書き換えられる.

$$
\frac{{ }_{B} \xi}{H}=\frac{{ }_{T} \xi}{H-{ }_{T B} h_{r}}
$$

これを ${ }_{T B} h_{r}$ こついて整理すると, 次式が得られる.

$$
{ }_{T B} h_{r}=\left(1-\frac{{ }_{T} \xi}{{ }_{B} \xi}\right) H \quad \cdots(6)
$$

したがって, 補修高さ $h_{r}$ は, 局部座屈の発生位置によって, 以下 のように定められる.

\section{【補修板下部に局部座屈を発生させる場合 (B)】}

$$
{ }_{T B} h_{r} \leqq h_{r} \quad \cdots(7 . \mathrm{a})
$$

【補修板上部に局部座屈を発生させる場合 $(T) 】$

$$
L_{B}<h_{r}<_{T B} h_{r} \quad \cdots(7 . b)
$$

ここで, $L_{B}$ : 局部座屈領域であり, 文献 18) に基づき, $L_{B}=0.8(0.17+0.032 B / t)$ (※ただし, $0.8 B$ 以下 $)$ とする

本実験の範囲では, ${ }_{B} \xi=1.15$ (隙間 $\left.s=40 \mathrm{~mm}\right)(1.05(s=60 \mathrm{~mm}))$, ${ }_{T} \xi=0.91$ であったため, ${ }_{T B} h_{r}=0.21 H(0.13 H)$ が得られる.これは 3.1.1項で述べたようにせん断スパンに応じた補修高さにより局部座 屈の発生位置が決まった結果と合致する.また, 本実験では ${ }_{T B} h_{r}=$ $306.6 \mathrm{~m}(189.8 \mathrm{~mm})$ となり, 補修高さが $300 \mathrm{~mm}$ 以上の場合に局部座 屈が補修板下部に発生した結果をおおよそ説明できるものとなって 
いる.さらに, 既往の実験 ${ }^{15)}$ においては ${ }_{T B} h_{r}=312.0 \mathrm{~mm}$ となり, や はり $\square 175$ の断面に補修高さ $200 \mathrm{~mm}$ の 4 面補修によって補修板上 部に局部座屈が発生した結果と合致する.

\subsubsection{4 面補修後の最大耐力}

4面補修を施した角形鋼管柱の最大耐力 $M_{\text {max }}$ は, 局部座屈の発生 位置により異なる.補修板を4.1.1項の仕様に従って設置すれば, 補 修後の最大耐力は, 以下の通りに整理できる.

【補修板下部に局部座屈を発生させる場合 (B)】

$$
M_{\text {max }}={ }_{B} \xi \cdot{ }_{0} M_{\text {max }} \quad \cdots(8 . \mathrm{a})
$$

\section{【補修板上部に局部座屈を発生させる場合 $(T) 】$}

$$
M_{\max }={ }_{T} \xi \cdot{ }_{0} M_{\max } \cdot \frac{H}{H-{ }_{T B} h_{r}} \quad \cdots(8 . \mathrm{b})
$$

なお, 本実験結果の範囲では ${ }_{B} \xi=1.15(s=40 \mathrm{~mm}), 1.05(s=60 \mathrm{~mm})$, ${ }_{T} \xi=0.91$ であり,これらの值が補修設計時の参考となる.

\subsubsection{4 面補修後の塑性変形能力}

4面補修を施した角形鋼管柱の塑性変形能力 $R$ は, 対象断面 (種別 $\mathrm{FC}$, 幅厚比 33.3) に対して4.1.1 項の仕様に従った補修板を設置す れば, 軸力比の大きさによって決まる.本実験で得られた補修後の 塑性変形能力と, 部材種別の必要值の参考 ${ }^{21)}$ に基づいて下限值を定 めれば, 補修後の塑性変形能力を以下のように与えられる.

$$
\begin{aligned}
& n=0.15 \text { のとき } R=4 \quad \cdots(9 . \mathrm{a}) \\
& n=0.30 \text { のとき } R=2 \quad \cdots(9 . \mathrm{b})
\end{aligned}
$$

\section{22 面補修を用いた被災後補修法}

\section{2.12 面補修の適用範囲と補修板の仕様}

本補修法は, 損傷した角形鋼管柱における局部座屈変形 $e$ が $20 \mathrm{~mm}$ 未満, かつ損傷度 $D$ が 0.46 以下の場合に適用できる.この適 用範囲は, 本実験において凹部の変形を連続溶接できた実績に基づ いて定めたものである.つまり, 大きな凹部の変形を避けて断続溶 接せざるを得ない場合は, 補修効果が得られない.

カバープレートを構成する補修板は, 厚さ $t_{r}$ を鋼管厚の 1 ～ 2 サ イズアップの厚さとし, 補修高さ $h_{r}$ は4 面補修にて局部座屈を補修 板下部 (B) に発生させられる高さを基本とする.また, それ以外の 寸法は, 溶接部も含めて 4 面補修に準じる. なお, 2 面補修では凸 部に補修板を取り付ける必要がなく, 矯正の作業を省略できる.

\subsection{2 面補修後の最大耐力}

2面補修を施した角形鋼管柱の最大耐力 $M_{\text {max }}$ は, 補修した凹部が フランジになるか, ウェブになるかによって異なる.補修後の柱脚 端における最大耐力の初期損傷時からの上昇率をそれぞれ ${ }_{2 F} \xi,{ }_{2 W} \xi$ とおけば, 補修後の最大耐力は以下のように整理できる.

$$
\begin{aligned}
& \text { 【補修部がフランジとなる場合 }(\mathrm{R} F) \text { 】 } \\
& M_{\max }={ }_{2 F} \xi \cdot{ }_{0} M_{\max } \\
& \text { 【.・(10.a) }
\end{aligned}
$$

\section{【補修部がウェブとなる場合 $(\mathrm{RW}) 】$}

$$
M_{\max }={ }_{2 W} \xi \cdot{ }_{0} M_{\max } \quad \cdots(10 . \mathrm{b})
$$

なお，本実験結果の範囲では ${ }_{2 F} \xi=1.00,{ }_{2 W} \xi=0.94$ であり,これら の值が補修設計時の参考となる.

\section{2.32 面補修後の塑性変形能力}

2面補修を施した角形鋼管柱は, 対象断面(種別FC, 幅厚比33.3) に対して4.2.1項の仕様に従った補修板を設置すれば, 少なくとも 元断面 (初期損傷時) と同等以上の塑性変形能力 $R$ が確保できる結果 が得られたため, 補修前と同等であると考えておけばよい，

\section{5. まとめ}

本研究では, 損傷した角形鋼管柱へのカバープレート補修法を対 象とした構造実験を行い, 損傷度を考慮した被災後補修法の構築を 検討した.以下に得られた結果をまとめる。

[1] 4面補修では,いずれの試験体も補修によって耐力は残存耐力 より回復し, 最大耐力は初期損傷時よりも高くなった. 補修後 の局部座屈は, 補修高さによって補修板上部と下部のいずれか に発生するかが決まった。また, 補修板下部に局部座屈が発生 寸る方が, 耐力劣化の勾配が緩やかとなり, 塑性変形能力が高 い傾向にあった。

［2］種別FAの断面については, 損傷時の累積塑性変形量が相対的 に大きかったこともあり,軸力比 0.15 の場合には部材端の溶接 部が破断した.幅厚比の小さな断面については, 局部座屈変形 だけで損傷状態を判別できないため, 部材端部の累積塑性変形 量を考慮した補修法が別途必要である.

［3］凸部の矯正を省略できる2面補修では, 凹部の局部座屈変形が $20 \mathrm{~mm}$ 未満, かつ損傷度が 0.46 以下であれば, 板厚を鋼管厚の 1〜2サイズアップした補修板を用いることにより，耐力は残 存耐力より回復し, 最大耐力は全塑性曲げモーメント以上と なった.また, 補修部がウェブとなる場合を含め, 無補修時と 同等以上の塑性変形能力を付与できた。

４］＜wide>カバープレート補修法 (4面補修, 2 面補修)について, 本実験 結果に基づいた適用範囲, 補修板の仕様を提示し, 最大耐力と 塑性変形能力の評価方法を示した。

なお, 本論文は, 文献14）の論文にて発表した内容に新たな実験 データを追加するとともに, データを再整理し, 加筆・修正したも のである。

\section{謝辞}

本研究は, JSPS 科研費 JP26420569, JP17H03339 の助成を受け たものです.構造実験については, 当時 大阪工業大学の卒論生で あった天方絵莉香さん (平成26年度), 千秋麻人君, 團野眞子さん, 平沼沙都さん (平成 27 年度), 橋本和也君 (平成 28 年度) の協力を得 て行いました.また, 東京工業大学に異動した後の研究遂行につい ては, 大阪工業大学 宮内靖昌教授に格別のご配慮をいただきまし た。ここに記して関係各位に謝意を表します。

\section{参考文献}

1) Hirosawa, M. et al. : Research Plan on Judgement for Damage Degree and Seismic Repair Techniques on Reinforced Concrete Buildings Damaged by EarthquakeNational Project • Development of Seismic Repair Techniques for Reinforced Concrete Structures (Part 1)-, Summaries of Technical Papers of Annual Meeting Architectural Institute of Japan, Structure, pp.2173-2174, 1983.9(in Japanese) 岡田恒男, 広沢雅也: 被災した鉄筋コンクリート造建物の被害度判定と復旧 技術に関する研究計画, 一総合プロジェクト・鉄筋コンクリート造震災構造 物の復旧技術の開発 (その1) - , 日本建築学会大会学術講演梗概集, 構造系, pp.2173-2174, 1983.9

2) Nabana, H. et al. : Effect of Strengthening and Repair on the Local Buckling Behavior of Steel Structural Members, Part 2 Test Results, Summaries of Technical 
Papers of Annual Meeting Architectural Institute of Japan, Structure, pp. 1250-1251, 1983.9(in Japanese)

鈴木弘之, 那花弘之: 鋼構造部材の局部座屈補強・補修後の耐力, その 2 実 験結果, 日本建築学会大会学術講演梗概集, 構造系, pp.1250-1251, 1983.9

3) Tanaka, A., Izumi, M. and Narihara, H. : Experimental Study on the Statical Characteristics of Repaired Steel Structures Severely Damaged due to Earthquake, Journal of Structural Engineering, Vol.35B, pp.411-423, 1989.3(in Japanese) 田中淳夫, 泉 満, 成原弘之: 震災をうけた鋼構造骨組の復旧法に関する実 験的研究, 構造工学論文集, Vol.35B, pp.411-423, 1989.3

4) Tanaka, A., Izumi, M. and Narihara, H. : Experimental Study on the Statical Characteristics of Repaired or Reinforced Steel Structures, Journal of Structural Engineering, Vol.36B, pp.377-383, 1990.3(in Japanese)

田中淳夫, 泉 満, 成原弘之 : 幅厚比の大きな柱材の震災復旧法および而震 補強法に関する実験的研究, 構造工学論文集, Vol.36B, pp.377-383, 1990.3

5) Suzutani, J. et al. : Restoration of Damaged Steel Buildings in Miyagi-ken-oki Earthquake, AIJ Tohoku Chapter Research Meeting, pp.9-12, 1981.2(in Japanese) 鈴谷二郎, 山田大彦, 山田聖志, 川名秀人, 桂 重衛, 吉田正紀 : ’78 宮城 県沖地震で被害を受けた鉄骨造建物の補修復旧状況, 日本建築学会東北支部 研究発表会, pp.9-12, 1981.2

6) Architectural Institute of Japan : Kenchikunenpou (Reports of the S57 AIJ Annual Meeting, Journal of Architecture and Building Science), pp.66-68, 1983.4(in Japanese)

日本建築学会 : 建築年報 (大会 - 論文編) 昭和 57 年度大会 (東北) 報告 研究 協議会一構造＼cjkstart震災構造物の損傷評価之修復 (青山博之, 木村栄一), pp.66$68,1983.4$

7) The Japan Building Disaster Prevention Association : Guidelines for Post-earthquake Damage Evaluation and Rehabilitation of Buildings and Houses, 2016.3(in Japanese)

日本建築防災協会:震災建築物の被災度区分判定基準および復旧技術指針， 2016.3

8) Sakamoto, S. et al. : Repair and Strengthening of Steel Beam-ends at Beam-tocolumn Connections, Journal of Constructional Steel, Vol.4, pp.159-166, 1996.11(in Japanese)

坂本真一, 矢部喜堂, 真瀬伸治, 山野辺宏治, 寺田岳彦: 鋼構造柱梁接合部 における梁端仕口部の補修補強に関する研究, 鋼構造年次論文報告集, 第4 巻, pp.159-166, 1996.11

9) Usami, T. et al. : Flange Fracture Behavior and Effect of Repairing or Strengthening at Beam End Adjacent to Beam-to-column Joint, Journal of Constructional Steel, Vol.4, pp.167-172, 1996.11(in Japanese)

宇佐美徹, 金子洋文, 木村 衛, 畧 博志, 櫛部淳道 : 梁端仕口部のフラン ジ破断および補修補強効果について, 鋼構造年次論文報告集, 第 4 巻, pp.167-172, 1996.11

10) Harada, Y. et al. : Experimental Study on Repair and Modification of Beam-toColumn Connection in Steel Building, Journal of Structural and Construction Engineering (Transactions of AIJ), No.553, pp.97-104, 2002.3(in Japanese)

原田幸博, 鄭 聖 珢, 森田耕次 : 鋼構造柱梁接合部の補修・補強方法に関 寸る実験的研究, 日本建築学会構造系論文集, 第553号, pp.97-104, 2002.3

11) Takahashi, Y. et al. : Retrofit Technique for Steel Structural Buildings Damaged by the Hanshin-Awaji Earthquake, AIJ Journal of Technology and Design, No.1, pp.127131, 1995.12(in Japanese)

高橋泰彦, 藤谷芳男, 吉川 稔, 八木貞樹, 藤田佳広, 福本早苗 : 阪神・淡 路大震災で被害を受けた鋼構造建築物の復旧技術, 日本建築学会技術報告 集, 第 1 号, pp.127-131, 1995.12

12) Matsumoto, T. et al. : An Experimental Study on Repairability and Recovery of Structural Performance for Damaged H-Shaped Steel Members, AIJ Journal of Technology and Design, Vol.20, No.44, pp.139-142, 2014.2(in Japanese) 松本 健, 森 健士郎, 伊藤拓海, 崔 彰訓 : 局部座屈と亀裂が生じた H 形 鋼部材の補修方法と補修後の構造性能に関寸る実験的研究, 日本建築学会技
術報告集，第 20 巻，第44 号, pp.139-142, 2014.2

13) Iwasaki, Y. and Kishiki, S. : Seisimic Repairing to Steel Beams with Strength Degradation due to Local Buckling, Proceedings of Constructional Steel, Vol.22, pp.695701, 2014.11(in Japanese)

岩㟝祐介, 吉敷祥一: 局部座屈により耐力劣化した梁の補修に関する実験, 鋼構造年次論文報告集，第 22 巻, pp.695-701, 2014.11

14) Iwasaki, Y. and Kishiki, S. : Seismic Repair and Damage Evaluation of RHS Column with Strength Degradation due to Local Buckling, Proceedings of Constructional Steel, Vol.23, pp.521-526, 2015.11(in Japanese)

岩﨑祐介, 吉敷祥一: 局部座屈により而力劣化した角形鋼管柱の簡易な損傷 評価法と補修，鋼構造年次論文報告集，第23 巻，pp.521-526，2015.11

15) Mori, K. et al. : An Experimental Study on Repair Method and Recovery of Structural Performance for Damaged RHS Steel Members, AIJ Journal of Technology and Design, Vol.22, No.52, pp.971-976, 2016.10(in Japanese)

森 健士郎, 伊藤拓海, 宗村大翔, 布施 拡, 崔 彰訓 : 局部座屈が生じた 角形鋼管部材の補修方法と補修後性能に関する実験的研究, 日本建築学会技 術報告集，第 22 巻，第 52 号, pp.971-976, 2016.10

16) Kishiki, S. and Iwasaki, Y. : Evaluation of Residual Strength based on Local Buckling Deformation of Steel Column, -Quick Inspection Method for Steel Structures based on the Visible Damage Part 3-, Journal of Structural and Construction Engineering (Transactions of AIJ), Vol.82, No.735, pp.735-743, 2017.5(in Japanese) 吉敷祥一, 岩㟝祐介 : 局部座屈変形に基づく鋼柱の残存耐力評価, - “見え る損傷” の定量化に基づく鋼構造骨組の即時損傷評価法 その $3-$, 日本建 築学会構造系論文集, 第 82 巻, 第 735 号, pp.735-743, 2017.5

17) National Institute of Land and Infrastructure Management, Building Research Institute : 2015bankenchikubutsunokouzoukankeikijyunkaisetsusyo (Instruction Manual of Technical Standards affiliated with the Building Standards Law related to Building Structures), 2015.6

国土技術政策総合研究所, 建築研究所: 2015 年版 建築物の構造関係技術基 準解説書, 2015.6

18) Yamada, S. et al. : Post-buckling and Deteriorating Behavior of Box-section Steel Members, Journal of Structural and Construction Engineering (Transactions of AIJ), No.444, pp.135-143, 1993.2(in Japanese)

山田 哲, 秋山 宏, 桑村 仁 : 局部座屈を伴う箱形断面部材の劣化域を含 む終局挙動, 日本建築学会構造系論文集, 第444 号, pp.135-143, 1993.2

19) Yamada, S. et al. : Hysteresis Model of RHS Columns in the Deteriorating Range governed by Local Buckling, Journal of Structural and Construction Engineering (Transactions of AIJ), Vol.77, No.674, pp.627-636, 2012.4(in Japanese) 山田 哲, 石田孝徳, 島田侑子: 局部座屈を伴う角形鋼管柱の劣化域におけ る履歴モデル, 日本建築学会構造系論文集, 第77巻, 第674号, pp.627-636, 2012.4

20) Architectural Institute of Japan : AIJ Recommendations for Plastic Design of Steel Structures, p.189, 2017.2(in Japanese)

日本建築学会 : 鋼構造塑性設計指針, 第3 版, p.189, 2017.2

21) Nippon Steel Corporation : Quarterly Column, No.82, p.36, 1981.10(in Japanese) 新日本製鐵株式會社 : 季刊 カラム, No.82, p.36, 1981.10

22) Kotake, T. et al. : An Experimental Study on Plastic Deformation Capacity of Hshaped Column with Stiffeners, Part 2 Test results of stiffened specimens, Summaries of Technical Papers of Annual Meeting Architectural Institute of Japan, C-1, pp.709-710, 2010.9(in Japanese)

小竹知哉, 聲高裕治, 長谷川隆, 伊藤隆之 : スチフナ補強された $\mathrm{H}$ 形断面 柱の塑性変形能力確認実験, その 2 補強試験体の実験結果, 日本建築学会 大会学術講演梗概集, C-1 分冊, pp.709-710, 2012.9 


\title{
SEISMIC REPAIR TO THE DAMAGED RHS COLUMN \\ WITH STRENGTH DETERIORATION DUE TO THE LOCAL BUCKLING
}

Development of seismic repair for the damaged steel members Part 1

\author{
Shoichi KISHIKI* and Yusuke IWASAKI** \\ * Assoc. Prof., FIRST, IIR, Tokyo Institute of Technology, Dr.Eng. \\ ** Former Grad. Student, Osaka Institute of Technology, M.Eng. \\ (Nose Structural Engineering)
}

From lessons learned after the 2011 Tohoku earthquake, it is clear that the quick procurement of an emergency public shelter and restoration of the city function are very important in the event of a disaster. Structural engineers are required to estimate the seismic damage of structural components in buildings, and to judge whether these are able to be repaired or not. However, seismic repair method considering damage degree for steel structural members has not been established, although most of the damaged buildings have been repaired after the 1995 Kobe earthquake. In the previous papers, visible damage indices for exposed column base, a single brace with angle section, and column have been established from the experimental studies.

This paper focuses on effects of the seismic repair to the residual out-of-plane deformations in local buckling region of steel column. In order to establish the seismic repair method considering the damage degree, cyclic loading tests of a steel column under axial compression force were carried out. The main parameter of the specimen is the cross section of the column, which are cold-formed RHS-200x6 (depth $\mathrm{x}$ thickness), 200x9, 300x9. In addition, the constant axial force which is 0.15 and 0.30 defined as the ratio to its yield axial strength is also selected as one of the parameters of the test. The experiments are consisted of two phases. The first tests were conducted to cause a local buckling to the column. Here, damage degree, the strength deterioration, is one of the test parameter. And then, the damaged column being repaired, the second tests were conducted to investigate effects of the seismic repair on the maximum strength, plastic rotation capacity, and region of local buckling. In this research, two repair methods were applied as follows: one is to attach the additional plates to all surfaces of column (RA series); and the others are to attach the plates to two surfaces which are flange or web in the concave (RF, RW series). In the case of RA series, the convex surfaces had to be made as flat as possible.

The major findings obtained from the test are summarized as follows: (1) the RA repair method brought the strength recovery from the residual strength and the maximum strength is larger than the original one; (2) RF and RW repair method also brought the strength recovery from the residual strength, however, the maximum strength is roughly same as the plastic moment of the original column; (3) finally, a simple seismic repair procedure using the additional plate to the damaged column is proposed.

(2017 年 4 月 3 日原稿受理， 2017 年 9 月 25 日採用決定) 